Research Article

\title{
The relationship between burnout syndrome and boreout syndrome of secondary school teachers during COVID-19
}

\author{
Radka Čopková \\ Technical University of Košice, Slovakia
}

\begin{abstract}
Coronavirus incidence causes the adoption of strict restrictions by governments in most of the countries. There were and still are public areas that are affected more than others - services and schools. In Slovakia, the school closure happened in the middle of March 2020 and lasts until May 2021. This situation puts a huge demand on teachers on all stages. This paper was to describe the difficult situation that occurred worldwide during the spring in 2020. We have focused on 214 secondary school teachers $\left(\mathrm{M}_{\mathrm{age}}=46.9 ; \mathrm{SD}=11.2 ; 75.3 \%\right.$ females $)$ and their experiences of two dangerous syndromes connected with job performance - burnout and boreout syndrome. Maslach Burnout Inventory (Ráczová \& Köverová, 2020) saturated by 3 subscales: depersonalization $(\alpha=0,903)$, personal accomplishment $(\alpha=0,624)$ and exhaustion $(\alpha=0,883)$ and Boreout scale $(\alpha=0,550)$ (Rothlin \& Werder, 2014) were administered. The convenience and purposive sampling method has been used. The data were proceeded by descriptive and correlation analysis (Pearson correlation coefficient). Statistical differences were tested with T-test for independent samples. We found that the level of both syndromes was not high during the first wave of COVID-19 pandemic, but female teachers experienced significantly higher emotional exhaustion than their male colleagues. Currently, after the second wave of pandemics, the need for a second round of the research arises what would create the opportunity for comparison.
\end{abstract}

Keywords: Burnout syndrome; Boreout syndrome; COVID-19; Secondary school teacher

Article History: Submitted 13 January 2020; Revised 11 April 2021; Published online 12 June 2021

\section{Introduction}

Restrictions adopted by the government to eliminate the spread of the COVID-19 virus began to be introduced in Slovakia in mid-March 2020. The strict lockdown affected almost all sectors of work, but especially services and education. Pupils and students at all levels (primary school, secondary school, university) have not gone to school for a year and are educated via distance learning. Undoubtedly, this places high demands not only on pupils, students and their parents, but also on teachers. Teachers in fact had to change the method of teaching from traditional to distance learning, which, among other things, brought up a problem with ICT equipment of schools (Košir

Address of Corresponding Author

Radka Čopková, PhD, Department of Engineering Education, Technical University of Košice, Košice, Slovakia.

radka.copkova@tuke.sk

0000-0001-6395-0300

How to cite: Čopková, R. (2021). The relationship between burnout syndrome and boreout syndrome of secondary school teachers during COVID-19. Journal of Pedagogical Research, 5(2), 138-151. http://dx.doi.org/10.33902/JPR.2021269824 
et al., 2020). Although a relatively long time has passed, changes in school attendance often change overnight, which places extremely high demands on teachers' flexibility (Collie, 2021). Many teachers also encounter negative attitudes from parents of students or society because distance learning requires greater involvement of parents in the education of their children, which does not suit many. Teachers thus become the target of anger and frustration, as many people believe that they do not put enough effort to educate pupils and students when working from home (Klapproth et al., 2020). An equally important element in teachers' lives is their personal lives (MacIntyre et al., 2020).

Teaching has long been regarded as a difficult vocation, even before the COVID-19 pandemic (Schaufeli et al., 2008). Typical stressors that teachers struggle under normal circumstances include time constraints, need for work-life balance connected with role conflict or ambiguity (parent vs. teacher), limited autonomy, excessive administrative obligations, problematic cooperation with colleagues and the director, managing innovations, emotional problems, fear from losing control of the class, fear of evaluation, and low professional self-esteem (Mercer \& Gregersen, 2020). Petrie (2020) identified other stressors that result from the current pandemic situation - insufficient support in the use of ICT in distance learning; disoriented students fearing the adverse consequences of distance learning on their academic performance; overloaded parents and the interrelationships of these three elements. In Slovakia, Loziak et al. (2020) examined stressors of female primary school teachers during COVID-19 pandemic. The results showed that the biggest stressors they had to face were lack of professional acknowledgment, putting extra hours for preparation and extra non-planned working hours.

Excessive experience of stress leads to the occurrence of negative consequences in an individual's life. If we talk about experiencing long-term work stress, it can result in burnout syndrome or boreout syndrome (Makasheva et al., 2016). For this reason, our research aimed to examine the relationship between burnout syndrome and boreout syndrome in secondary school teachers during the stress period of the COVID-19 pandemic. Secondary schools represent a transition between childhood and adulthood. While at primary school the presence and involvement of the parent also play an important role in the study process, at, the university the students themselves are mainly responsible for their study performance and study results. Secondary school students are precisely the group that is no longer so dependent on the control of study performance by parents (who do not have to master the teaching material), but they are not yet quite self-reliant as to be independent of the teacher's involvement in the teaching process. This could be the reason for increased strain on secondary school teachers, which could lead to undesirable effects like boreout and burnout syndrome.

\subsection{Burnout Syndrome and Boreout Syndrome}

Burnout syndrome is a phenomenon explicitly linked to work performance. Some authors (Barnett \& Flores, 2016) point out that since both work and school are places where some pressure is put on individuals, burnout can also occur within students. Burnout is defined as the psychological syndrome of emotional exhaustion, depersonalization and reduced personal accomplishment, that occurs mainly among workers who encounter other people at work (Maslach \& Leiter, 2017). Over time, however, some reports have emerged that nowadays it is no longer a phenomenon typical for helping professions, but also occurs in other professions. Therefore, the revised version of the definition of burnout syndrome refers to symptoms in the context of unsolvable work stress (Maslach et al., 2001). Emotional exhaustion is the most important symptom of burnout syndrome and relates to the feeling of exhaustion of one's own emotional energy, predicting most health consequences caused by stress. Depersonalization is seen as a dysfunctional way of dealing with emotional exhaustion, meaning an emotional cutting off from work. Reduced personal accomplishment from work refers to a negative assessment of one's own work performance and the overall value of work (Leiter et al., 2014). 
Just as burnout syndrome is often automatically associated with helping professions, boreout syndrome is often associated with office work, e.g. in corporations (Rozvadský-Gugová \& Heretik, 2011). Moris and Nedosugova (2019) state that in terms of personality, workers who follow the expectations of others and are intimidated by them, are more prone to boreout syndrome. Also, individuals need constant stimulation in the form of changing stimuli and highly intelligent workers who need a constant supply of challenges that they could face. Risk factors on the part of the job description are e.g., insufficient variability of work activities, fulfillment of long-term goals. Rothlin and Werder (2011) identified three basic components of boreout syndrome - inexperience that occurs when an employee can perform more job responsibilities than he currently has; indifference to conducted work and boredom in which the employee loses the joy of work and experience feelings of helplessness because they do not know what to do. Stock (2013) also talks about three aspects of boreout syndrome - the crisis of the meaning of work (perceived senselessness); tedious employment (the level of stimulation is perceived as unsatisfactorily low); limited job growth (lack of learning and self-development opportunities).

Several authors have addressed the relationship between these two variables (Brnula \& Mokráňová, 2013; Lovašová \& Jungová, 2018; Rothlin \& Werder, 2014). According to Rothlin and Werder (2014), boreout is the opposite of burnout. Other authors find many common elements between the two syndromes. The consequences of burnout and boreout syndrome are found on cognitive (lack of attention), emotional (anxiety, stress, loss of beliefs in one's own ability, helplessness, lack of self-confidence, lack of enthusiasm), physiological (dizziness, headache, stomachache, vomiting, psychosomatic problems, exhaustion), and behavioral (absenteeism, job change) levels (Lovašová \& Jungová, 2018; Rozvadský-Gugová \& Heretik, 2011; Tóthová \& Žiaková, 2018).

The difference between burnout and boreout syndrome lies in the source of stress that leads to its development. While at burnout, the source of stress is excessive employee overload, at the boreout, it is the exact opposite - underload. Additionally, stress in burnout syndrome is also associated with the fear that the inefficient work of the employee will be exposed. In contrast, boredom in the workplace is undesirable compared to exhaustion from a large amount of work (Rozvadský-Gugová \& Heretik, 2011).

In their work, Lovašová and Jungová (2018) refer to Brnul and Mokráňová (2013) and Campagne (2012) (as cited in Lovašová \& Jungová, 2018), who point to possible causal relationships between the two syndromes. According to the mentioned authors, boreout predicts burnout, as it can be a cause of disappointment, which is considered one of the negative factors in the development of burnout syndrome. They do not rule out the possibility of parallel occurrence of both syndromes.

\subsection{Burnout and Boreout in Teaching Profession}

Nowadays, the teaching profession is considered one of the riskiest in terms of developing burnout (Schaufeli et al., 2008). In this context, Sears et al. (2000) speak of the syndrome that affects physical, academic and social performance in teaching that emerges in response to a long-term stressful working conditions. Reduced teacher performance results in reduced interest in their students, colleagues, and parents of students, leaving a negative impression on the people they come in contact with (Baran et al., 2010). Van Horn et al. (1997) specifically highlighted the issue of burnout in high school teachers and described it as a serious occupational hazard. Travers and Cooper (1993) point out that teachers' stress levels were significantly higher than the average stress levels of other professionals in the helping professions.

The key variables that are considered to support developing of the burnout symptoms in teachers tend to be grouped into two categories - personality and contextual. Personality variables have been discussed in several studies and have included personality traits, perceived self-efficacy, existential fulfillment, constructive thinking, engagement, age, gender, length of practice, motivation to learn, willingness to work, abilities (Baran et al., 2010; Loonstra et al., 2009). Aloe et 
al. (2014) summarized the findings on the length of practice and the grade at which the teacher teaches, pointing out that younger teachers tend to experience a higher degree of burnout than older colleagues, as well as high school teachers compared to those teaching in primary schools. Contextual factors include educational system, the quality of the educational institutions, workload, school equipment, time pressure, working conditions, lack of recognition, legislative changes, social support, relationships between colleagues, student learning problems, large classes, and so on (Aloe et al., 2014; Baran et al., 2010; Fiorili et al., 2015; Loonstra et al., 2009). Teacher burnout syndrome can lead to absences that have a direct impact on students' academic performance, greater punishment of kids, or disinterest in them (Aloe et al., 2014).

Although the boreout syndrome primarily affects office workers, research findings suggest that boredom is not avoided even in the teaching profession, which we classify as helping professions. Given the above, there are still few resources that would address the issue of boreout syndrome and the teaching profession. According to Rogozinsky (2018), a teacher's ennui might stem from a variety of factors. If the teacher has been teaching for more than a few years, they will sooner or later encounter boredom. This is especially the case if they teacher the same subject, degree and lesson. This is mainly due to the fact that teachers are one of the few employees who have a stable way of working in the performance of their profession. Year after year, they work with the same academic material and meet mostly only small changes.

Boredom in teachers was studied by Keller et al. (2014). In this research, teachers reported that they experience a significant amount of boredom from teaching in the classroom, in about a quarter of all lessons. Since boredom is generally deemed a mental state with low arousal and deactivation, the authors say the result requires further investigation because it is at odds with the active role that the teacher must exercise during the lesson. Although boredom in teaching is still considered undesirable, at present the trend of an active role of the pupil prevails compared to the teacher, who is supposed to play a rather passive role. Boredom in college teachers was studied by Sohail et al. (2010) in relation to age and gender. The results indicated that boredom is related to age, which supports the hypothesis that higher age and thus longer practice are associated with a higher propensity for boredom, because longer practice is associated with a lack of variety and less content changes (Lovašová \& Jungová, 2018). While in the research of Sohail et al. (2010) did not confirm the relationship between boredom and gender, the research of Vodanovich et al. (2011) suggested that men are more prone to boredom than women.

The present study examined burnout syndrome and boreout syndrome in a sample of high school teachers during the first wave of the COVID-19 pandemic. Specifically, the following subobjectives were set:

To determine the level of burnout syndrome and boreout syndrome in secondary school teachers during COVID-19, the relationships between burnout syndrome and boreout syndrome and to identify differences between teachers from vocational and general schools and gender differences in experiencing of burnout and boreout during COVID-19.

\section{Method}

\subsection{Research Design}

This quantitative research used a correlational research design (Pallant, 2011) to investigate the strength and direction of the linear relationship between two variables, burnout syndrome and boreout syndrome. The study, on the other hand, focused on the comparison of different groups in terms of some variables introduced in the following sections.

\subsection{Population and Sampling}

Because of pandemic, convenience and purposive sampling method have been used. A total of 214 secondary school teachers in Slovakia aged 25 to 73 participated in the research $\left(\mathrm{M}_{\mathrm{age}}=46.9 ; \mathrm{SD}=11.2\right)$. Men accounted for $24.7 \%$ of respondents $(\mathrm{N}=53)$ aged 25 to 66 years $\left(\mathrm{M}_{\mathrm{age}}=44.3 ; \mathrm{SD}=12.1\right)$ and women accounted for $75.3 \%$ of respondents $(\mathrm{N}=161)$ aged 25 to 73 
years $\left(\mathrm{M}_{\text {age }}=47.7 ; \mathrm{SD}=10.8\right)$. There were $49 \%$ of respondents $(\mathrm{N}=105)$ with an average length of practice of $19.5(\mathrm{SD}=10.2)$ years who worked at a vocational school and $51 \%$ of teachers $(\mathrm{N}=109)$ with an average length of practice of 18.4 years who worked at a general school $(\mathrm{SD}=12)$. The total length of practice ranged from 0 to 45 years $(\mathrm{M}=18.9$; $\mathrm{SD}=11.2)$.

\subsection{Data Collection}

The set of questionnaires used in the study consisted of three parts - sociodemographic data, one adopted measure - Maslach Burnout Inventory and one modified measure - Boreout Scale. The description of all measures is mentioned below.

Sociodemographic data - age, gender, school type (vocational/general), length of practice.

Maslach Burnout Inventory - MBI - HSS (Ráczová \& Köverová, 2020). The questionnaire is an adapted Slovak version based on the original MBI - Human Services Survey (Maslach \& Jackson, 1981). It consists of 22 items that saturate the three subscales - depersonalization - DP (5 items "My work exhausts me emotionally."), personal accomplishment - PA (8 items - "I feel I have a positive effect on other people's lives through my work.") and emotional exhaustion - EE (9 items - "I'm afraid my work makes me emotionally cool."). The respondent sign answers on a 7 -point scale $(0$ - never; $1=$ several times a year; $3=$ once a month or less; $3=$ several times a month; $4=$ once a week; $5=$ several times a week; 6 = daily) indicates the frequency of occurrence of the symptoms formulated in each item. Items in the personal accomplishment subscale are reverse coded. The final score is calculated as the sum of the points marked by the respondent for each subscale separately. Minimum score in all subscales is 0, maximum score in emotional exhaustion subscale is 36, in depersonalization subscale 30 and in personal accomplishment subscale 48 . The indicators of the internal consistency of the scales expressed by the Cronbach alpha coefficient were as follows $\mathrm{a}_{\mathrm{ee}}=0,903 ; \mathrm{a}_{\mathrm{pa}}=0,624 ; \mathrm{a}_{\mathrm{dp}}=0,883$.

Boreout scale - BO (Rothlin E Werder, 2014). The original scale consists of 10 items ("I feel unoccupied and bored at work."), the respondent answers dichotomously - yes or no. For the purposes of our research, we changed the dichotomous response scale to a 6-point Likert scale, on which the respondents expressed the degree of their agreement, resp. disagreement with statements about experienced boredom in the workplace $(1=\mathrm{I}$ do not experience at all; $6=\mathrm{I}$ still experience). The final score is calculated as the sum of the points marked by the respondent. The minimum score that can be achieved is 6-maximum 60 . The indicators of the internal consistency of the scales expressed by the Cronbach alpha coefficient were .55 .

The questionnaires were submitted to respondents in the period March 2020 - April 2020 in an electronic version created in the Google Docs-Form web application. At first directors of secondary schools were asked to join their school into the research. After they agreed, they have been asked to disseminate the web link with the set of questionnaires to the teachers.

Respondents were informed that completing the questionnaire is voluntary and anonymous and that data will only be processed in the framework of this research. All respondents expressed their agreement to participate in the research.

\subsection{Data Analysis}

There were no missing data in the dataset. Testing the normality of data distribution using the Kolmogorov-Smirnov test showed that the data are normally distributed ( $p \geq .05)$. Descriptive indicators of the normality of data distribution indicated that the value of the skewness and kurtosis did not exceed the criterion $> \pm 1$. Internal consistency was determined using Cronbach's alpha (Cronbach $a$ ). The obtained data were described using other descriptive indicators (mean, standard deviation). Relationships between variables were tested by the Pearson correlation coefficient. Statistical differences were tested with t-test for independent samples. The collected data were analyzed in IBM SPSS Statistics 21. 


\section{Results}

Following the main aim of this study - examination of burnout syndrome and boreout syndrome in a sample of high school teachers during the first wave of COVID-19 pandemic - several analyses were conducted.

Firstly, we assumed that the levels of burnout and boreout syndromes will be above the average for teachers. Next, descriptive analysis (Table 1) has been conducted to determine the level of burnout and boreout syndrome in high school teachers during the first wave of the COVID-19 pandemic.

Table 1.

Descriptive statistics of MBI - HSS and BO, 2020 (source: author)

\begin{tabular}{lccccc}
\hline & $M$ & $M e$ & $S D$ & Min & Max \\
\hline BO & 23.20 & 22.00 & 4.72 & 13.00 & 42.00 \\
EE & 17.10 & 15.00 & 10.40 & 0.00 & 43.00 \\
DP & 2.68 & 2.00 & 2.97 & 0.00 & 11.00 \\
PA & 29.80 & 34.00 & 12.50 & 5.00 & 48.00 \\
\hline
\end{tabular}

MBI - HSS = Maslach Burnout Inventory - Human Services Survey; $B O=$ boreout syndrome; EE=emotional exhaustion; $D P=$ depersonalization; $P A=$ personal accomplishment; $M=$ mean; $M e=$ median; $S D=$ standard deviation .

The results suggest that at the time of the first lockdown, secondary school teachers did not experience symptoms of any studied syndromes. Given the extent to which respondents could score on each scale, these results are favorable. In the boreout scale, the average value was 27.5 , but in our sample, respondents reached 23.20, indicating that they did not feel bored. In the subscale of emotional exhaustion, the average is 18.5 , respondents reached a median value of 17.10. This result suggests that teachers did not feel emotionally exhausted at the time of the first lockdown, but this value can be considered as borderline. In depersonalization, the respondents were completely different, where the average scale value is 15.5 , but the respondents reached the value of 2.68 . The result of personal accomplishment looks favorable because teachers scored at the median level of 29.8, which is more than the possible average scale value - 24.5. For better understanding, the results are showed in Figure 1.

Figure 1

$M B I-H S S$ and $B O$

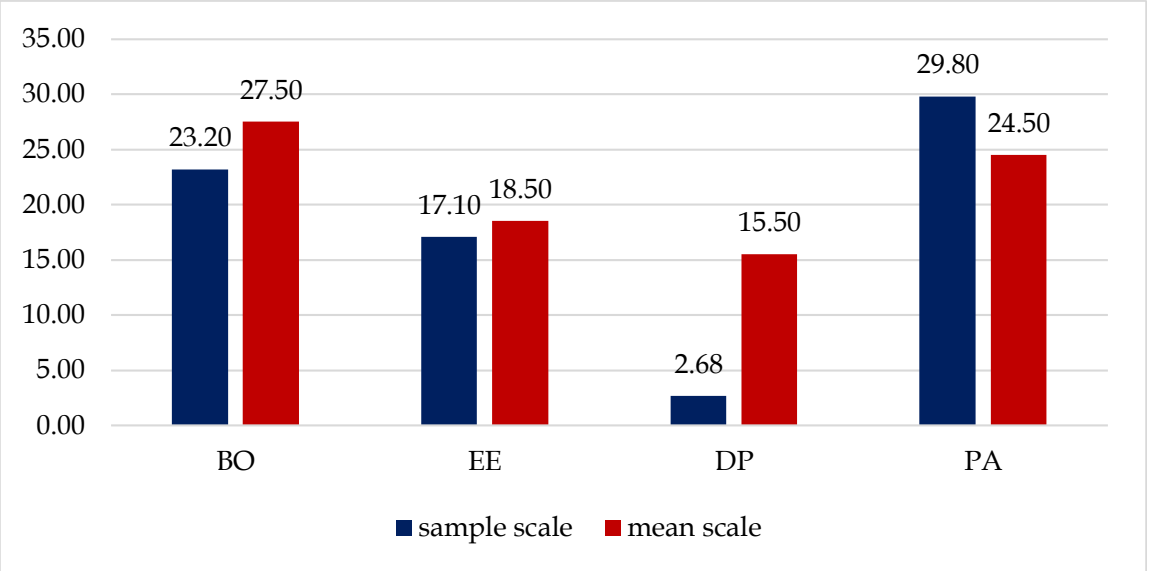

MBI - HSS = Maslach Burnout Inventory - Human Services Survey; BO=boreout syndrome; EE=emotional exhaustion; $\mathrm{DP}=$ depersonalization; $\mathrm{PA}=$ personal accomplishment

In the next step, we divided the sample of teachers according to the type of school they teach in. The ratio of teachers from general secondary schools to vocational secondary schools was almost the same. This was a good assumption for comparing whether there were differences between the two groups of teachers in burnout and boreout syndrome during the first wave of the COVID-19 
pandemic. We assumed that teachers from vocational schools will score higher than teachers from general schools in emotional exhaustion and depersonalization, lower in personal accomplishment and boreout.

Descriptive indicators suggest (Table 2) that secondary vocational school teachers have reached a lower average of boreout value than secondary general school teachers, and at the same time, these values are lower than the possible average scale value (27.5). Nevertheless, testing did not show a statistically significant difference in the level of boreout syndrome between teachers from different types of secondary schools. Teachers from secondary general schools had a higher value of the average of emotional exhaustion than teachers from secondary vocational schools. Their average value was even closer to the average scale value (18.5). From the above, we can assume that general school teachers were more emotionally exhausted, but testing did not confirm that this difference was significant. In depersonalization, teachers from both types of schools scored much lower than the average scale value (15.5). Teachers from secondary vocational schools scored slightly higher than teachers from secondary general schools, but this difference was not significant. The result concerning personal accomplishment is quite surprising. Descriptive indicators suggest only minimal differences between teachers from both types of schools, as confirmed by testing. However, more surprisingly, the averages of the respondents are higher than the average scale value (27.5).

Table 2

T-test for independent samples - school type differences

\begin{tabular}{|c|c|c|c|c|c|c|c|c|c|c|}
\hline & School & $N$ & $M$ & $M e$ & $S D$ & Min & Max & $t$ & $p$ & $d$ \\
\hline \multirow{2}{*}{$\mathrm{BO}$} & $V$ & 105 & 23.00 & 22.00 & 4.71 & 13.00 & 42.00 & \multirow{2}{*}{-0.694} & \multirow{2}{*}{0.488} & \multirow{2}{*}{-0.095} \\
\hline & G & 109 & 23.50 & 22.00 & 4.75 & 15.00 & 36.00 & & & \\
\hline \multirow{2}{*}{$\mathrm{EE}$} & $V$ & 105 & 16.30 & 15.00 & 9.46 & 0.00 & 41.00 & \multirow{2}{*}{-1.202} & \multirow{2}{*}{0.231} & \multirow{2}{*}{-0.164} \\
\hline & G & 109 & 18.00 & 17.00 & 11.20 & 0.00 & 43.00 & & & \\
\hline \multirow{2}{*}{ DP } & V & 105 & 2.70 & 2.00 & 3.04 & 0.00 & 11.00 & \multirow{2}{*}{0.085} & \multirow{2}{*}{0.932} & \multirow{2}{*}{0.012} \\
\hline & G & 109 & 2.66 & 1.00 & 2.91 & 0.00 & 11.00 & & & \\
\hline \multirow{2}{*}{ PA } & $V$ & 105 & 29.60 & 33.00 & 12.20 & 5.00 & 47.00 & \multirow{2}{*}{-0.207} & \multirow{2}{*}{0.836} & \multirow{2}{*}{-0.028} \\
\hline & G & 109 & 30.00 & 35.00 & 12.70 & 500 & 48.00 & & & \\
\hline
\end{tabular}

$\mathrm{BO}=$ boreout syndrome; $\mathrm{EE}=$ emotional exhaustion; $\mathrm{DP}=$ depersonalization; $\mathrm{PA}=$ personal accomplishment; $\mathrm{V}=$ vocational high school; $\mathrm{G}=$ general high school

These results reveal that vocational secondary school teachers and general secondary school teachers experienced the beginning of the first lockdown approximately the same, with no signs of burnout syndrome and boredom syndrome. For better understanding, the results are shown in Figure 2.

In the next step, we divided the sample of teachers by gender. The ratio of male to female teachers was not the same. However, this reflects the real staffing of male and female individuals as teachers, as the profession is still considered dominated by women (Wilbourne \& Kee, 2010). Nevertheless, we investigated whether there were differences between the two groups of teachers in burnout and boreout syndrome during the first wave of the COVID-19 pandemic. We assumed that men will score higher in boreout syndrome, women will score higher in burnout syndrome. Descriptive indicators show (Table 3) that men and women have reached the same mean boreout value, and at the same time, these values are lower than the possible mean scale value (27.5). Of course, testing did not show a statistically significant difference in the level of boreout syndrome between men and women. However, women had a higher value of the average emotional exhaustion than men. Their average value was even closer to the average scale value (18.5). From the above-mentioned, we can assume that women were more emotionally exhausted than men. This assumption was also confirmed by testing. Contrariwise, in depersonalization, men scored higher than women, but the values were still lower than the average scale value (15.5). 
Figure 2

$M B I-H S S$ and $B O$ - school type

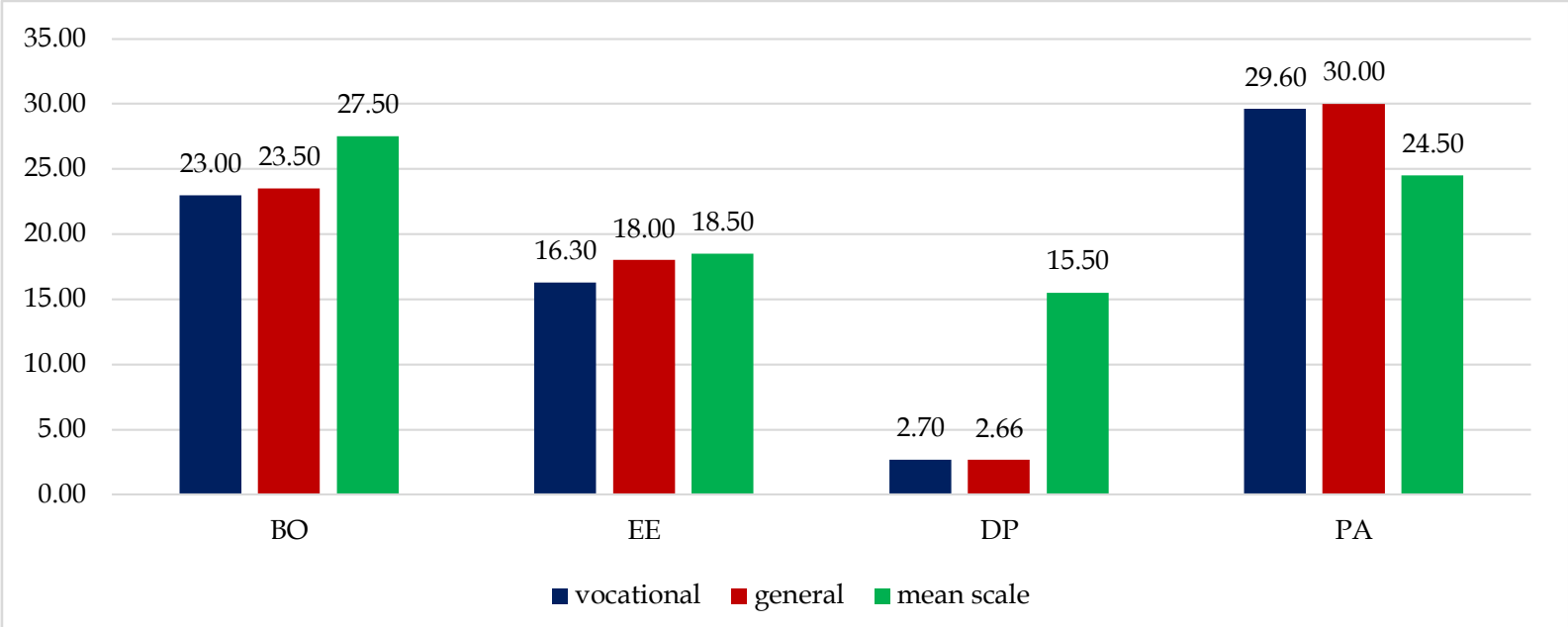

MBI - HSS = Maslach Burnout Inventory - Human Services Survey; BO=boreout syndrome; EE=emotional exhaustion; $\mathrm{DP}=$ depersonalization; $\mathrm{PA}=$ personal accomplishment

Despite the expected differences, these differences in depersonalization did not appear to be significant. Descriptive indicators in the personal accomplishment subscale indicate only minimal differences between men and women, which was also confirmed by testing. The average achieved values of the respondents are higher than the average scale value (27.5).

Table 3

T-test for independent samples - gender differences

\begin{tabular}{llccccccccc}
\hline & Gender & $N$ & $M$ & $M e$ & $S D$ & Min & Max & $t$ & $p$ & $d$ \\
\hline \multirow{2}{*}{ BO } & Male & 53 & 23.20 & 23.00 & 4.71 & 13.00 & 35.00 & \multirow{2}{*}{0.034} & \multirow{2}{*}{0.970} & -0.005 \\
& Female & 161 & 23.30 & 22.00 & 4.75 & 15.00 & 42.00 & & & \\
\hline \multirow{2}{*}{ EE } & Male & 53 & 14.20 & 12.00 & 10.40 & 0.00 & 43.00 & \multirow{2}{*}{2.406} & \multirow{2}{*}{$0.017^{\star}$} & -0.381 \\
& Female & 161 & 18.10 & 17.00 & 10.20 & 0.00 & 43.00. & & \multirow{2}{*}{0.180} & \multirow{2}{*}{0.212} \\
\hline \multirow{2}{*}{ DP } & Male & 53 & 3.15 & 3.00 & 3.00 & 0.00. & 11.00 & \multirow{2}{*}{1.340} & \multirow{2}{*}{0.180} \\
& Female & 161 & 2.52 & 1.00 & 2.95 & 0.00. & 11.00 & & \multirow{2}{*}{0.053} \\
\multirow{2}{*}{ PA } & Male & 53 & 29.30 & 35.00 & 13.60 & 7.00. & 48.00 & \multirow{2}{*}{0.334} & \multirow{2}{*}{0.739} & -0.053 \\
& Female & 161 & 30.00 & 34.00 & 12.10 & 5.00. & 48.00 & &
\end{tabular}

$\mathrm{BO}=$ boreout syndrome; $\mathrm{EE}=$ emotional exhaustion; $\mathrm{DP}=$ depersonalization; $\mathrm{PA}=$ personal accomplishment

These results show that male and female teachers experienced the beginning of the first lockdown differently in the dimension of emotional exhaustion. Despite these differences, the level of burnout and boreout syndrome was not high in either group. On the contrary, despite signs of emotional exhaustion, teachers also experienced sufficient personal accomplishment. For better understanding, the results are shown in Figure 3.

Another partial goal of the study was to examine the relationships between boreout syndrome, burnout syndrome factors, age and length of practice. We assumed that the relationship between burnout and boreout will be significant - positive with emotional exhaustion and depersonalization, negative with personal accomplishment. 
Figure 3

$M B I-H S S$ and $B O-$ gender

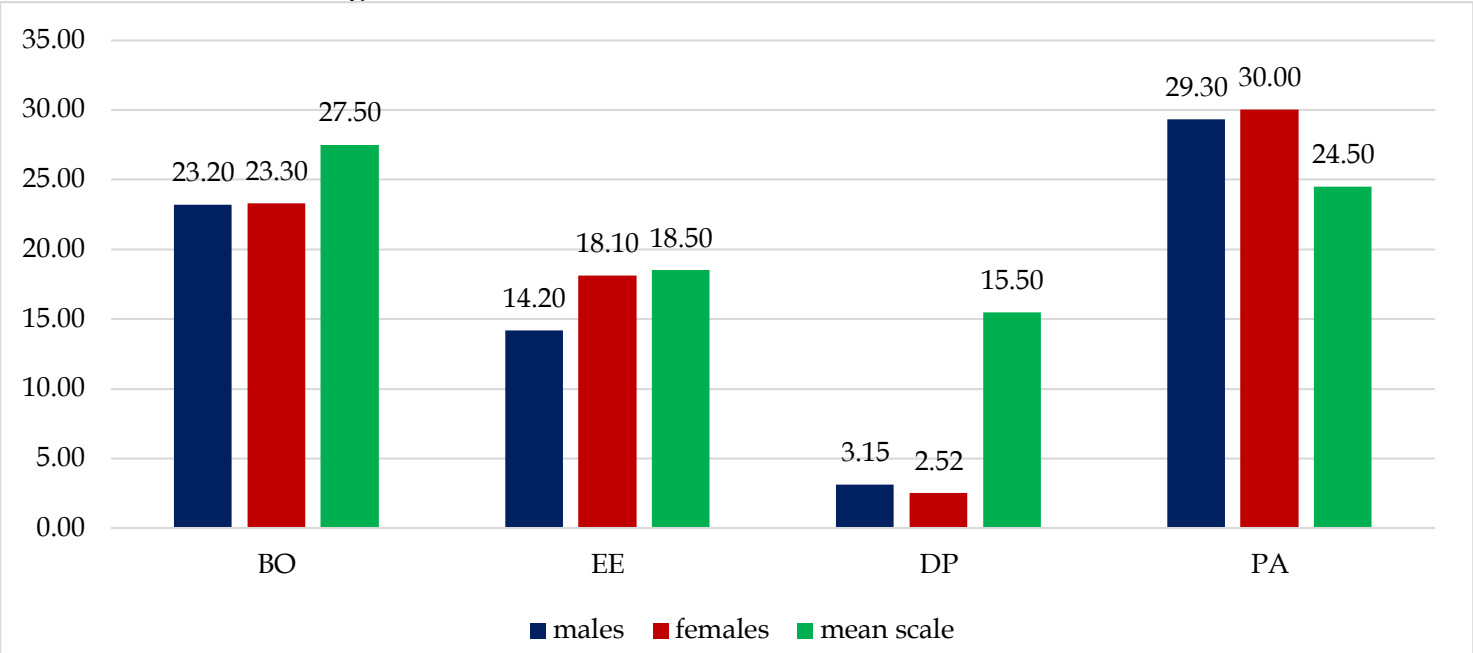

MBI - HSS = Maslach Burnout Inventory - Human Services Survey; BO=boreout syndrome; EE=emotional exhaustion; $\mathrm{DP}=$ depersonalization; $\mathrm{PA}=$ personal accomplishment

The results in Table 4 suggest that boredom syndrome was significantly positively correlated with emotional exhaustion, depersonalization, and length of practice. The correlation with emotional exhaustion was moderately strong, weak with depersonalization. This means that with the increasing incidence of boredom and the development of boreout syndrome, the likelihood of emotional exhaustion and depersonalization increases. Also, with increasing years of teaching practice, the risk of symptoms of boreout syndrome increases, but this relationship was weak. Boreout syndrome had a weak significant negative relationship with age. This suggests that the incidence of boreout syndrome should decrease with age.

Surprisingly, no significant relationship between the length of teaching practice and age with emotional exhaustion, depersonalization and personal accomplishment was demonstrated.

Table 4

Pearson correlation matrix of $M B I-H S S, B O$, age and length of practice

\begin{tabular}{lcccccccc}
\hline & $M$ & $S D$ & $B O$ & $E E$ & $D P$ & $P A$ & age & practice \\
\hline BO & 23.20 & 4.72 & - & & & & & \\
EE & 17.10 & 10.40 & $0.416^{* * *}$ & - & & & & \\
DP & 2.68 & 2.97 & $0.187^{* *}$ & $0.219^{* *}$ & - & & & \\
PA & 29.80 & 12.50 & -0.089 & -0.114 & -0.084 & - & & \\
Age & 46.90 & 11.20 & $-0.227^{* *}$ & 0.020 & -0.025 & 0.101 & - & \\
Practice & 18.90 & 11.20 & $0.161^{*}$ & 0.083 & -0.035 & 0.005 & $0.836^{* * *}$ & -
\end{tabular}

$\mathrm{BO}=$ boreout syndrome; $\mathrm{EE}=$ emotional exhaustion; $\mathrm{DP}=$ depersonalization; $\mathrm{PA}=$ personal accomplishment; ${ }^{*} \mathrm{p}<0.05^{* *} ; \mathrm{p}<0.01 ;{ }^{* * * *} \mathrm{p}<0.001$

\section{Discussion}

The present study aimed to examine two negative phenomena that are associated with the performance of work on a sample of secondary school teachers in a specific situation - lockdown during the first wave of the COVID-19 pandemic (March 2020). The research is specific because of several elements. First, it is a matter of sample selection. Teachers in secondary schools were chosen because teaching in secondary schools is based not only on a theoretical basis, but also on a practical basis, especially in secondary vocational schools. Part of the lockdown in Slovakia was the closure of schools at all levels. Unfortunately, the situation in secondary schools did not change in a year, high school students were in school only for 1.5 months (September - middle October 
2020). The teaching process is conducted exclusively in a distance form, which places high demands on teachers. Students in secondary schools are not yet as independent as students at universities, so teachers have the main responsibility for students' learning outcomes. Compared to primary school pupils, secondary school students are less dependent on the help of parents, who often do not understand the specific content of the taught material, because they are e.g. experts in a completely different field. Therefore, teachers in secondary schools cannot even rely on the help of parents. This is the reason why very high demands are placed on their mental health and performance. The second specific element of the research is the context in which the research took place. Exploring the relationship between burnout and boreout is not new (Brnula \& Mokráňová, 2013; Lovašová \& Jungová, 2018; Rothlin \& Werder, 2014), but the situation of COVID-19 is. It was an unexpected and completely new situation, which modern Europe and the Western world had no experience with so far. At the time of the first lockdown, no one knew for how long the situation would be critical. At present, however, much research has begun to focus on burnout, coping (Mercer \& Gregersen, 2020), stress (Loziak et al., 2020), work-life balance (Mercer \& Gregersen, 2020), job performance (Petrie, 2020) during a pandemic, which makes sense in the current situation.

Several research aims were set. At first we aimed to determine the level of burnout and boreout syndrome in secondary school teachers during COVID-19. During the data collection, we encountered several negative reactions from teachers. Their anger lays in startle by how in such a critical and unpredictable situation we can ask questions about boredom experiencing. This reaction was also reflected in the result, which confirmed our assumption that teachers did not experience boreout to an increased extent. Despite the sharp negative reaction that encouraged us to believe that teachers would score high in emotional exhaustion and depersonalization, this assumption was not confirmed. We explain this result by the fact that in the first wave of lockdown, teachers were in the initial phase, when the situation was relatively short, the demands were not quite high because we all thought that this situation would last a month or two and not more than a year. We assume that the teachers still had enough internal resources, they entered the pandemic with the odds in their favor to manage its demands.

Next, we aimed to to identify the differences between teachers from vocational and general schools in experiencing burnout and boreout during COVID-19. Due to this objective, the next step was the testing of the differences in burnout and boreout between teachers teaching at different types of schools - vocational and general. We assumed that vocational secondary school teachers would score higher in emotional exhaustion and depersonalization and lower in personal accomplishment and boreout than general secondary school teachers. We assumed that there is more practical teaching at secondary school, which is directly connected with a stay in laboratories and technically/practically specialized classrooms, where students can work directly with instruments, devices or other materials. In the conditions of distance teaching, such teaching is impossible. Therefore, vocational secondary school teachers need to make greater efforts to provide students with a quality education. This assumption of ours has not been confirmed. The differences in the mentioned variables were not significant. However, we can note that in all the mentioned variables, teachers from general school achieved slightly higher results.

Another goal we have set was to examine of gender differences between teachers in high school teachers in experiencing burnout and boreout during COVID-19. We assumed that men would score higher in boreout and women higher in burnout. This assumption was partially confirmed. We observed significantly higher emotional exhaustion in women than in men. We assume that women are more exhausted because, in addition to work responsibilities, they are also more demanded in the area of caring for their own children and the home (MacIntyre et al., 2020). The second important fact is that male experiencing is more rational, while women are more emotionally based (Lutz \& White, 1996) and therefore more at risk of burnout.

The last aim of the study was the examination of the relationships between burnout syndrome and boreout syndrome in high school teachers during COVID-19. Testing the relationship between 
boreout and burnout supported the hypothesis that boreout is the prerequisite for burnout (Brnula \& Mokráňová, 2013; Campagne, 2012 as cited in Lovašová \& Jungová, 2018). In our research, boreout correlated positively with emotional exhaustion and depersonalization. This means that the more intense the experience of boreout syndrome is, the more likely it is emotional exhaustion and depersonalization. Boreout syndrome was negatively correlated with age and positively with length of practice. This means that with increasing age, the probability of developing boreout syndrome is lower, but with increasing practice, higher. This result may appear contradictory, however it is important to note that the age and duration of practice are not the same. Not all teachers devote their entire professional lives to teaching career. As a result, it's likely that a younger teacher has more experience teaching than an older teacher. In other words, teachers may have learned stronger coping skills as their experience grew (Skaalvik \& Skaalvik, 2015), but on the other hand, they may be more subject to the dullness in their work (Lovašová \& Jungová, 2018). Interestingly, the relationship between burnout and age and length of practice was not shown in our sample.

The question remains, how hold up the teachers in the first and second degree of primary schools, following the example of Loziak et al. (2020). It is no less important to think about university teachers, as research to date suggests that burnout and boreout do not avoid them either (Azeem \& Nazir, 2008; Sohail et al., 2010; Watts \& Robertson, 2011). It is also appropriate to support introducing of innovative teaching methods so that neither students (Daschmann et al., 2011) nor teachers will be bored (Keller et al., 2014; Rogozinsky, 2018).

\section{Conclusion}

This research examined experiences of secondary school teachers during the first wave of COVID19 pandemic connected with strict restrictions adopted by the government. Authors have focused on two dangerous syndromes that may occur during job performance - burnout and boreout syndrome. Surprisingly, the results have shown low level of emotional exhaustion and depersonalization as well as high level of personal accomplishment. The level of boreout syndrome was found on the expected level. In spite of preliminary assumptions based on developmental issues of the students and practical orientation of the teaching process at vocational schools, there were no significant differences found between teachers from different school types. Also, there were no gender differences found, except for emotional exhaustion. As expected, females scored significantly higher. Several significant relationships have been found, specifically boreout syndrome had significant positive relationships with depersonalization and emotional exhaustion what met our assumptions. However, the relationship with personal accomplishment was weak and non-significant.

This research also has limitations. We cannot generalize the results, as the COVID-19 pandemic is a specific situation. At the beginning of the pandemic during the first lockdown, teachers did not know what awaits them. Therefore, it is important to conduct similar research at one-year intervals. However, not only teachers are exhausted, but also parents and the whole society because no one knows when the pandemic ends. As a limit, we also see that there were no teachers from other high school type in the sample. There were no medical or service secondary school teachers present. Furthermore, the adopted versions of questionnaires were employed, which could result in a problem with translation, resulting in lower reliability coefficients. Criteria for assessment consider the value as insuffiscient, however with a small number of items, Cronbach's alpha values around 0.50 are also acceptable (Field, 2016).

\subsection{Recommendations}

We advocate redoing study with a time gap as a future direction. The current circumstance, following the conclusion of the second wave of the COVID-19 pandemic, presents a unique chance to collect new data and compare it to data collected after the first wave of the pandemic. We believe our findings are a solid beginning point for future study that might broaden the research 
sample to include a variety of schools in terms of professional specialization and degree. During a pandemic, we also believe that focusing on specific components of work (stressors) that lead to the development of burnout and boreout syndrome is critical. As parents' negative sentiments of teachers continue to rise, this will make it possible to intervene in the form of awareness-raising programs for parents about the teacher's profession, perhaps reducing stress, frustration, and conflict on both sides.

\section{References}

Aloe, A. M., Shisler, S. M., Norris, B. D., Nickerson, A. B., \& Rinker, T. W. (2014). A multivariate metaanalysis of student misbehavior and teacher burnout. Educational Research Review, 12, 30-44. https://doi.org/10.1016/j.edurev.2014.05.003

Azeem, S. M., \& Nazir, N. A. (2008). A study of job burnout among university teachers. Psychology and Developing Societies, 20(1), 51-64. https:// doi.org/10.1177/097133360702000103

Baran, G., Bıçakçı, M. Y., İnci, F., Öngör, M., Ceran, A., \& Atar, G. (2010). Analysis of burnout levels of teacher. Procedia-Social and Behavioral Sciences, 9, 975-980. https://doi.org/10.1016/j.sbspro.2010.12.270

Barnett, M. D., \& Flores, J. (2016). Narcissus, exhausted: Self-compassion mediates the relationship between narcissism and school burnout. Personality and Individual Differences, 97, $102-108$. https://doi.org/10.1016/j.paid.2016.03.026

Brnula, P., \& Z. Mokráňová, (2013). Súvislosti syndrómu nudy a syndrómu vyhorenia u sociálnych pracovníkov a možnosti psychosociálnej opory. Profesionalita, perspektivy a rozvoj sociální práce: zborník z konferencie X. Hradecké dny sociální práce v Hradec Králové [Professionalism, perspectives and development of social work], In H. Králové (Ed.) : Proceedings of the conference X., Hradec Králové Days of Social Work (pp. 186 - 194) Gaudeamus.

Collie, R. J. (2021). COVID-19 and Teachers' somatic burden, stress, and emotional exhaustion: examining the role of principal leadership and workplace buoyancy. AERA Open, 7(1), 1-15. https://doi.org/10.1177/2332858420986187

Daschmann, E. C., Goetz, T., \& Stupnisky, R. H. (2011). Testing the predictors of boredom at school: Development and validation of the precursors to boredom scales. British Journal of Educational Psychology, 81(3), 421-440. https:/ / doi.org/10.1348/000709910x526038

Field, A. (2016). An adventure in statistics: The reality enigma. Sage.

Fiorilli, C., Gabola, P., Pepe, A., Meylan, N., Curchod-Ruedi, D., Albanese, O., \& Doudin, P. A. (2015). The effect of teachers' emotional intensity and social support on burnout syndrome. A comparison between Italy and Switzerland. European Review of Applied Psychology, 65(6), $275-283$. https://doi.org/10.1016/j.erap.2015.10.003

Keller, M. M., Frenzel, A. C., Goetz, T., Pekrun, R., \& Hensley, L. (2014). Exploring teacher emotions. Routledge.

Klapproth, F., Federkeil, L., Heinschke, F., \& Jungmann, T. (2020). Teachers' experiences of stress and their coping strategies during COVID-19 induced distance teaching. Journal of Pedagogical Research, 4(4), 444452. https:/ / doi.org/10.33902/JPR.2020062805

Košir, K., Dugonik, Š., Huskić, A., Gračner, J., Kokol, Z., \& Krajnc, Ž. (2020). Predictors of perceived teachers' and school counsellors' work stress in the transition period of online education in schools during the COVID-19 pandemic. Educational Studies, 1-5. https:/ / doi.org/10.1080/03055698.2020.1833840

Leiter, M. P., Bakker, A. B., \& Maslach, C. (Eds.). (2014). Burnout at work: A psychological perspective. Psychology Press.

Loonstra, B., Brouwers, A., \& Tomic, W. (2009). Feelings of existential fulfilment and burnout among secondary school teachers. Teaching and Teacher Education, 25(5), $752-757$. https://doi.org/10.1016/j.tate.2009.01.002

Lovašová, S., \& Jungová, I. (2018). Boreout a burnout syndróm v kontexte starostlivosti o seba. [Boreout and burnout syndrome in the self-care context]. In H. Králové (Ed). Evropské pedagogické fórum [European pedagogical forum] (pp. 393-402) Magnanimitas.

Loziak, A., Fedáková, D., \& Čopková, R. (2020). Work-related stressors of female teachers during covid-19 school closure. JWEE, (3-4), 59-78. 
Lutz, C. A. (1990). Engendered emotion: Gender, power, and the rhetoric of emotional control in American discourse. In C. A. Lutz, \& L. Abu-Lughod (Eds.), Studies in emotion and social interaction. Language and the politics of emotion (pp. 69-91). Editions de la Maison des Sciences de l'Homme.

MacIntyre, P. D., Gregersen, T., \& Mercer, S. (2020). Language teachers' coping strategies during the Covid19 conversion to online teaching: Correlations with stress, wellbeing and negative emotions. System, 94. https://doi.org/10.1016/j.system.2020.102352

Makasheva, N., Makasheva, J., Groomova, A., Ishtunov, S., \& Burykhin, B. (2016). The problem of professional burnout in stress management. SHS Web of Conferences, 28, 34-39. Available from: https://www.shsconferences.org/articles/shsconf/pdf/2016/06/shsconf_rptss2016_01132.pdf

Maslach, C., \& Leiter, M. P. (2017). Understanding burnout: New models. In C. L. Cooper \& J. C. Quick (Eds.), The handbook of stress and health: A guide to research and practice (pp. 36-56). Wiley Blackwell.

Maslach, C., Jackson, S. E., Leiter, M. P., Schaufeli, W. B., \& Schwab, R. L. (1986). Maslach burnout inventory, 21, 3463-3464.

Maslach, C., Schaufeli, W. B., \& Leiter, M. P. (2001). Job burnout. Annual Review of Psychology, 52(1), 397-422. https://doi.org/10.1146/annurev.psych.52.1.397

Maslach, C., Leiter, M.P. \& Schaufeli, W.B. (2008). "Measuring burnout". In Cooper, C.L. and Cartwright, S. (Eds), The Oxford Handbook of Organizational Wellbeing (pp. 86-108). Oxford University Press.

Mercer, S., \& Gregersen, T. (2020). Teacher wellbeing. Oxford University Press.

Moris, H., \& Nedosugova, A. B. (2019). Coaching as instrument to identity and remedy for boreout syndrome with employees. In W. Striełkowski (Ed.), Advances in social science, education and humanities research (ESSD 2019) (pp. 138-141). Atlantis Press.

Pallant, J. (2011). SPSS survival manual: A step by step guide to data analysis using IBM SPSS. Allen \& Unwin.

Petrie, C. (2020). Current opportunities and challenges on Covid-19 in education. Spotlight: Quality education for all during Covid-19 crisis. OECD/Hundred Research Report \#011.

Ráczová, B., \& Köverová, M. (2020). A confirmatory factor analysis of the Slovak version of the MBI-HSS for helping professions, Československá Psychologie, 64(3), 272 - 287.

Rogozinsky, D. (2018). Teachers: What to do if you're the one who's bored in class [online]. https://study.com/blog/teachers-what-to-do-if-you-re-the-one-who-s-bored-inclass.html

Rothlin, P., \& Werder, P. (2011). El nuevo sindrome laboral boreout: recupera la motivación [The new boreout work syndrome: get your motivation back]. Penguin Random House Grupo Editorial España.

Rozvadský-Gugová, G., \& Heretik, A. (2011). Robotizmus, workoholizmus, fenomény dnešnej doby. [Robotizmus, workoholizmus, phenomena of our time], In K. Benková, \& L. Vavrysová (Ed.), Sborník z mezinárodní vědecké konference [Proceedings of an international scientific conference] (pp. 603-610). Societas Scientiarum Olomoucensis II.

Sears, S. F., Urizar, G.G. and Evans, G.D. (2000). Examining a stress-cping model of burnout and depression in extension agents. Journal of Occupational Health Psychology, 5, 56-62. https://doi.org/10.1037//10768998.5.1.56

Skaalvik, E. M., \& Skaalvik, S. (2015). Job satisfaction, stress and coping strategies in the teaching professionwhat do teachers say?. International Education Studies, 8(3), 181-192. http://dx.doi.org/10.5539/ies.v8n3p181

Sohail, N., Ahmad, B., Tanveer, Y., \& Tariq, H. (2012). Workplace boredom among university faculty members in Pakistan. Interdisciplinary Journal of Contemporary Research in Business, 3(10), 919-925.

Stock, R. M. (2013): A hidden threat of innovativeness: Service employee Boreout. In J. Burroughs, \& A. Rindfleisch (Eds.), AMA Winter Marketing Educators' Conference Proceedings: Challenging the Bounds of Marketing Thought (159 - 160). Curran Associates.

Tóthová, L., \& Žiaková, E. (2018). Výber neefektívnych stratégií zvládania zát’aže ako rizikový faktor v pomáhajúcich profesiách [Selection of inefficient coping strategies as Risk factor in helping professions]. In M. Köverová, \& M. Mesárošová (Ed.), Pomáhajúce profesie a starostlivost́ o seba z pohl'adu psychológie a sociálnej práce [Helping professions and self-care from the point of view of psychology and social work] (pp. 117-121). Košice: Univerzita Pavla Jozefa Šafárika v Košiciach.

Travers, C. J., \& Cooper, C. L. (1993). Mental health, job satisfaction and occupational stress among UK teachers. Work \& Stress, 7(3), 203-219. https://doi.org/10.1080/02678379308257062

Van Horn, J. E., Schaufeli, W. B., \& Enzmann, D. (1999). Teacher burnout and lack of reciprocity. Journal of Applied Social Psychology, 29(1), 91-108. https://doi.org/10.1111/j.1559-1816.1999.tb01376.x

Vodanovich, S. J. (2003). Psychometric measures of boredom: A review of the literature. Journal of Psychology, 137(6), 569-595. https:// doi.org/10.1080/00223980309600636 
Watts, J., \& Robertson, N. (2011). Burnout in university teaching staff: A systematic literature review. Educational Research, 53(1), 33-50. https://doi.org/10.1080/00131881.2011.552235

Wilbourn, M. P., \& D. W. Kee (2010). Henry the nurse is a doctor too: Implicitly examining children's gender stereotypes for male and female occupational roles. Sex Roles, 62(9-10), 670-683. https://doi.org/10.1007/s11199-010-9773-7 